\title{
Servidor republicano: \\ política nos "textos menores" de Maquiavel
}

(Re)public Servant:

politics in Machiavelli's 'minor texts'

"... se quisermos manter a liberdade..."

Maquiavel, "Discurso Proferido ao Magistrado

dos Dez Sobre a Situação de Pisa", 1499

A política, mesmo sendo uma desgraça, é necessária para manter a liberdade. Eis a característica inovadora do pensamento político de Maquiavel e a razão de seu interesse permanente. Essa é a mensagem maior das suas obras "menores" aqui analisadas (Maquiavel, 2010). ${ }^{1}$ Esse conjunto de trabalhos aplicados revela que a ciência política de Maquiavel é produto de sua vocação e identidade como servidor da república florentina. Murderous Machiavelli, dizia Shakespeare. Política diabólica (Chaui, 2000, p. 204). Ética feroz (Chisholm, 1998). Ler Maquiavel assusta, mas não se culpa o mensageiro pela mensagem: para manter a liberdade interna e externa, todos os cidadãos e todos os Estados enfrentam os dilemas da decisão política e as realidades da gestão pública.

Este artigo focaliza um conjunto de vinte e quatro textos escritos por Maquiavel, a maior parte enquanto servidor da república florentina (Silva,

É professor titular de sociologia política da Escola de Administração de Empresas de São Paulo da Fundação Getúlio Vargas (São Paulo, SP, Brasil). E-mail: kurt.mettenheim@fgv.br.

A expressão "obras menores" vem de duas coleções, Machiavelli (1852; 1961) e Marchand (1975). Os vinte e quatro textos analisados aqui são de uma tradução nova com textos inéditos publicados em Maquiavel (2010). Valverde (2010, p. 21) nota a publicação de onze textos menores em 1940 pela Athena Editora, que serviram de base para o volume Maquiavel da coleção Os Pensadores da editora Abril. 
2012; Valverde, 2010; Guidi, 2009). Pela sua redação para fins práticos e pela existência de pesquisas históricas (Montevecchi, 2007) e filológicas (Marchand, 1975), as obras menores de Maquiavel sobre a política apresentam novas oportunidades de análise, inclusive no sentido de aprofundar as leituras consagradas das obras principais de Maquiavel e ajudar a contornar seus limites interpretativos. Sobretudo, esses textos reforçam os estudos que enfatizam o republicanismo de Maquiavel (Ames, 2012; McCormick, 2011; Bock et al., 1990; Pockock, 1975; Plamenatz, 1972; Baron, 1961) e esclarecem o contexto das obras de Maquiavel na política interna e externa da Florença.

Os textos a serem analisados a seguir cobrem temáticas desde a diplomacia florentina e problemas administrativos, fiscais e políticos relacionados à mobilização de forças armadas, até relatos sobre a França e a Alemanha, memoriais e análises de instituições e de conjunturas políticas. São textos curtos, mas seus significados e importância não são menores. A maioria foi escrita quando Maquiavel era secretário na chancelaria de Florença. Portanto, esses textos tratam de problemas de política e de gestão, justamente enquanto sua república nova se encontra no meio de forças políticas novas, de Estados territoriais modernos emergentes como a França, a Espanha, a República Sagrada Romana², o Estado Papal, e cidades e Estados vizinhos, procurando reconciliar as novas capacidades comerciais e industriais com a incerteza política, ou seja, o início do século XVI renascentista.

Esses textos menores de Maquiavel ajudam a evitar a conclusão de que a ciência política de Maquiavel é uma apologia irrestrita à Realpolitik (Meinecke, 1957). Num sentido mais amplo, o fio que melhor serve de guia para o pensamento de Maquiavel pode ser encontrado, nas palavras de Benedetto Croce, no conceito de virtude política, que não é sinônimo nem negação de virtude moral (Mansfield, 1994; Ball, 1995, p. 65; Wood, 1967; Croce, 1925). Para muitos, Maquiavel foi o primeiro pensador político cientifico que abdicou dos valores éticos para mostrar o comportamento verdadeiro dos Estados (Berlin, 1997; Strauss, 1958). De fato, os conselhos no Príncipe podem parecer irreconciliáveis com a análise de repúblicas nos Discursos, pois o conceito novo de virtude (virtù) articulado por Maquiavel apresenta

Embora não usual, utilizamos o nome Sagrada República Romana, de Falco (1954), para enfatizar a continuidade republicana nas instituições políticas do imperador Maximiliano como também na vida e na obra de Maquiavel. 
afinidades com o conceito homérico e aristotélico ( $\alpha \rho \varepsilon \tau)$ pela sua definição de "excelências" próprias aos diferentes papéis políticos. Nessa volta aos clássicos, Maquiavel se afasta do consenso entre cristãos e pensadores da Roma antiga, como Cícero, que mantinham uma visão de virtude humanista abrangente, se não única. Portanto, a virtude apresenta três faces nas obras de Maquiavel; ora uma virtude para príncipes, analisada sobretudo no Príncipe, ora uma virtude cívica tratada nos Discursos e, finalmente, uma virtude militar, apresentada na Arte da guerra. Os textos menores sobre a política e a gestão florentina são especiais justamente pela colisão e combinação dessas três virtudes nas análises de ciência política aplicadas de Maquiavel. Nesses vinte e quatro textos encontramos um Maquiavel servidor público assumidamente republicano, especialmente antes da derrota da nova república florentina em 1512, quando forças monárquicas e estrangeiras trazem os Médici de volta à sua cidade, mudança de regime que leva ao seu afastamento, prisão domiciliar e tortura.

Para Maquiavel, a ação política numa república pode e deve se afastar do sentido medieval de virtude por causa de situações e de necessidades. Mas, do fato de que, em condições adversas, tais comportamentos são justificados, não se deve inferir demais. Se tomarmos o título que John Rawls (1985) usou para responder a seus críticos - "É a política, não a metafísica" -, podemos também qualificar a virtude política em Maquiavel. O dever da decisão política é o de manter a liberdade interna e externa dos cidadãos de um Estado (de preferência republicano) em meio a um fluxo de fatores que, em geral, são alheios ao controle e aos códigos morais simples. Assim, adotando os conceitos de Maquiavel, a política visa a domar a fortuna para assegurar a glória e a fama.

Longe de heroísmo, o tom de Maquiavel é de ceticismo e cautela (Ridolfi, 2003; Viroli, 1998). Por exemplo, os dois últimos textos aqui analisados tratam dos muros de Florença. Aqui Maquiavel sobriamente calcula, em vão, como conter a tomada militar da sua cidade, desta vez não pelas tropas do papa e das forças da reação monárquica, como em 1512, mas perante mais uma conjuntura terrível: o saque de Roma em 1527 por forças germânicas e espanholas. Então, antes de fechar um triangulo analítico entre os conceitos de fortuna, de glória e de fama para deixar o humanismo e a ética de fora (Godman, 1998), falta lembrar a nossa epígrafe. É da primeira frase do discurso proferido por Maquiavel ao Magistrado dos Dez sobre 
a situação de Pisa, já como secretário da chancelaria do Estado florentino em 1499. "Se quisermos manter a liberdade..."3. Eis o pressuposto maior do arcabouço analítico e a ciência política de Maquiavel. O ceticismo e o pessimismo de Maquiavel não são posições metafísicas, mas resultados de seu serviço público enquanto assistia a fatos históricos como o fim do regime republicano e da independência da sua cidade, a sua ocupação militar, e os abusos mais terríveis de mercenários e tropas de Espanha sobre seus conterrâneos.

Analisaremos, portanto, os vinte e quatro textos menores sobre a política a partir desse ponto de vista: de um Maquiavel assumidamente republicano e da política como necessidade para manter a liberdade interna e externa. Os objetivos desta análise são apresentar um novo olhar sobre Maquiavel, incentivar estudos mais profundos desses textos menores e apontar possíveis contribuições para interpretações da ciência política de Maquiavel que tendem a se concentrar em leituras do Príncipe, dos Discursos e da Arte da guerra, como também de suas outras obras maiores de história e de literatura e suas cartas. Também esperamos mostrar a necessidade de estudos mais profundos do corpo completo das obras de Maquiavel em legazioni e commissarie de serviço para a república florentina (Bertelli, 1964).

Antes, convém lembrar alguns pontos biográficos de Maquiavel. Em 1494, aos vinte e cinco anos de idade, Maquiavel entrou no serviço público florentino enquanto caíam do poder os Médici. Em 1498, o ano da execução de Girolamo Savonarola na praça principal de Florença, Maquiavel chegou à segunda chancelaria da Florença para servir como secretário do Comitê dos Dez, responsável pela defesa militar. Em 1505-6 assumiu a responsabilidade de alistamento militar e tentou implementar uma alternativa à contratação de mercenários (sua aversão a eles foi adquirida quando observou a desordem causada por tropas suíças e gascões usados por Florença para reprimir revoltas em Pisa em 1500). Ainda a serviço da sua cidade, participa de missões diplomáticas na França, no Vaticano e na Alemanha. Depois da retirada de tropas francesas da Itália em 1512 e de cair o gonfaloniere Piero Soderini, Lourenço de Médici e o Comitê de 70 acabam com o governo republicano e despedem Maquiavel. Assim, ao contrário das dúvidas que ainda perduram

Montevecchi (1986, p. 57) esclarece em nota que liberdade aqui é no sentido de acesso florentino ao mar. Mas, pelo contexto desse texto, e pela análise dos outros textos menores a seguir, sugerimos que sentidos mais amplos de liberdade republicana se inscrevem aqui também. 
sobre a composição, o propósito e o conteúdo do Príncipe, os textos menores de Maquiavel aqui analisados apresentam um contexto mais claro e registro de seu serviço ao governo republicano florentino.

Esses textos inspiram novas reflexões sobre a obra de Maquiavel. $L$ 'arte dello stato é diferente quando serve para manter a liberdade que cidadãos conquistaram num governo republicano no meio de monarquias e cidades medievais atreladas ao papa. Escapamos da sua metáfora violenta e machista da fortuna no capítulo XXV do Príncipe para reconhecer a habilidade de Maquiavel em captar como a história permanece aberta à ação política (Falko, 2004; Pitkin, 1984). Encontramos exemplos de sua sociologia política, que retrata histórica e estrategicamente lutas entre classes e apresenta a institucionalização dessas lutas como fundamental para a liberdade e a boa gestão. Podemos admirar também sua transformação de gêneros de trabalho do humanismo em narrativas enxutas. Por exemplo, os paradiastoles usados por Maquiavel transformam a significância moral dos comportamentos por sua própria descrição (Skinner, 1981). Dessa maneira, os textos menores ajudam a afastar os incômodos de uma leitura do Príncipe, mas mantêm a diferença do seu pensamento político sobre os textos do humanismo e da antiguidade. Mesmo para o Maquiavel servidor da república florentina, a força militar e a ação valem mais que a retórica e as palavras, a simplicidade vale mais que a eloquência, a experiência mais que a inteligência, e a esperteza mais que a integridade (Ball, 1994, p. 82).

Os vinte e quatro textos menores sobre a política de Maquiavel são considerados a seguir em cinco grupos. Os primeiros sete tratam principalmente da política exterior florentina. Em seguida, quatro textos discutem problemas políticos e fiscais relacionados à mobilização e à gestão de armas na defesa da cidade. O terceiro grupo, de seis textos, retrata as culturas políticas dos Estados territoriais emergentes e problemas diplomáticos enfrentados por Florença. O quarto grupo é de textos escritos depois de Maquiavel ser removido de seu cargo na chancelaria e mostra as ambiguidades e incertezas enfrentadas por ele fora do poder. Os últimos dois textos apresentam uma coda terrível, pois aqui Maquiavel relata seus esforços em vão para melhorar a estrutura e a funcionalidade dos muros de Florença. Como conjunto, esses textos menores de Maquiavel sobre a política esclarecem seu republicanismo e mostram como a sua ciência política surge de seu trabalho na Chancelaria da Florença republicana. 


\section{Textos menores sobre gestão e política exterior em Florença: “Discurso proferido ao Magistrado dos Dez sobre a situação de Pisa" (1499)}

O primeiro grupo de textos menores sobre política de Maquiavel trata de gestão e da política exterior em Florença. O "Discurso proferido ao Magistrado dos Dez sobre a situação de Pisa" foi escrito em 1499, aproximadamente um ano antes de Maquiavel participar em uma missão diplomática em Pisa. Neste discurso, que abre com a frase que serve de epígrafe e elo deste artigo - “... se quisermos manter a liberdade” -, Maquiavel capta a nova situação geopolítica e aponta uma janela de oportunidade inesperada para a retomada de Pisa pelas armas. Em 1494, as tropas de Carlos VIII, o rei da França, entraram na Itália e conquistaram o reinado de Nápoles. A chegada de Carlos VIII leva o povo de Pisa (o porto comercial mais próximo) a rebelar-se contra o controle de Florença. Assim começam quatorze anos de guerra entre Florença e Pisa, como também uma nova conjuntura política que isola a república florentina perante os Estados territoriais monárquicos emergentes, as suas cidades vizinhas competidoras comerciais em plena expansão (principalmente Milão, Gênova e Veneza) e as forças do Estado Papal. A obtenção de proteção pela França da cidade de Pisa, no dia 7 de novembro de 1494, corta o acesso de Florença ao mar e susta seu comércio. A saída de Piero de Médici de Florença também muda a política interna de Florença e inaugura um período republicano sob constante assédio e manobras do Estado Papal, de uma Veneza expansionista e das disputas entre França, Espanha e Sagrada República Romana.

Uma sequência de derrotas militares e retrocessos diplomáticos isola Florença. Mas a conjuntura política muda durante 1498. Em 1494, Florença resistiu a entrar na Liga Antifrancesa na procura de saídas diplomáticas. Em 1498, as iniciativas diplomáticas e militares de Roma, de Veneza e da Sagrada República Romana, como também das novas potências Espanha e França mudam e, inesperadamente, por diversas razões, todas essas forças se afastam da proteção de Pisa, a não ser Veneza. Portanto, Maquiavel argumenta a favor da retomada de Pisa pela força, não como princípio, nem como conselho para um príncipe e sim como cálculo político numa conjuntura nova favorável para a república à qual ele serve como secretário. O método notável de Maquiavel neste texto é utilizar antinomias sequencialmente para definir as opções de política exterior de Florença dentro da nova conjuntura geopolítica para o Magistrado dos Dez. 


\section{"Providências para a reconquista de Pisa" (1509)}

O segundo texto, "Providências para a reconquista de Pisa", foi escrito em 1509, portanto onze anos depois do primeiro discurso de Maquiavel sobre Pisa. Aqui Maquiavel discute as opções táticas para retomar Pisa à força, enfatizando os custos relativos de manter dois ou três pontos de ataque e acampamentos de apoio para cercar a cidade, como também as técnicas de assediar e tomar a cidade: "Para pôr termo à campanha de Pisa é necessário ou conquistá-la pelo assédio e pela fome, ou pela expugnação, com o uso da artilharia contra suas muralhas" (Maquiavel, 2010, p. 33). Como Maquiavel conclui que o assédio não poderia contar com a cooperação da cidade de Lucca, ele descreve como as forças de Florença teriam que assumir o controle de todos os acessos a Pisa.

Novamente, vale notar que a preferência de Maquiavel pela força militar na retomada de Pisa não tem base metafísica nem se fundamenta na teoria de Realpolitik e se dá, sim, com base de juízo empírico, depois de Maquiavel coordenar uma missão diplomática para Pisa, em março de 1509. De fato, quatro expedições militares Florentinas já haviam fracassado (em 1499, pelo mercenário Paolo Vitelli, em 1500, com tropas mercenárias da Gasconha e da Suíça, em 1504, numa tentativa de desviar o rio Arno e, em 1506, com mercenários italianos). Mas o contexto geopolítico favorecia novamente a opção militar. Devido ao rapprochement entre os reis de França e de Aragão, e a formação da Liga de Cambrai, que reunia esses reis e o imperador Maximiliano, o rei de Nápoles e os Estados Papais, a cidade de Florença já aceitara a oferta dos reis Ferdinando e Luis XII e pagado recompensa para reassumir pacificamente o controle de Pisa. Mas, justamente nas negociações junto às autoridades de Pisa, das quais Maquiavel participara, surge resistência à rendição incondicional contada como certa pela população de Florença. Portanto, aqui também a ciência política de Maquiavel se baseia em juízo empírico adquirido em serviço público à república florentina.

\section{“Notícias das medidas adotadas pela República Florentina para pacificar as facções de Pistoia" (1501)}

O terceiro texto, "Notícias das medidas adotadas pela República Florentina para pacificar as facções de Pistoia", relata os conflitos entre oligarquias depois da participação de Maquiavel como comissário de Florença em missão diplomática junto a Pistoia, em 1501. Este texto complementa as passagens 
consagradas de Maquiavel, no Príncipe e nos Discursos, ${ }^{5}$ sobre facções. Mas aqui Maquiavel enfatiza o momento político. O parágrafo final insiste em aproveitar o fato de estarem no exílio 150 líderes das duas facções para introduzir reformas internas que legitimariam e consolidariam o controle florentino sobre a cidade.

No dia 2 de fevereiro de 1501, Maquiavel foi enviado com "autoridade ampla” para resolver a situação de rebeldes pistoianos na cidade de Carmignano, justamente enquanto o exílio dos Panciatici ${ }^{6}$ ameaçava elevar a violência entre facções para uma guerra civil, que necessariamente envolveria Florença não só em conflitos em Pistoia mas também na gestão de refugiados, além do perigo de surgirem conflitos em cidades vizinhas. Mas a negociação da volta dos exilados para Pisa e a chance de evitar a polarização interna sofre um revés inesperado com a incursão militar na Toscana de César Bórgia, de Milão. Nesse contexto de crescente conflito interno e de um boato de uma possível reconciliação mediada por César Bórgia, que incluía a secessão de Pistoia do controle de Florença, Maquiavel é enviado novamente para a cidade em julho e agosto para se informar sobre a situação. Em 21 de agosto de 1501, Florença conclui um acordo entre as facções de Pistoia. Durante a fase mais crítica de negociações posteriores sobre a volta dos Panciatici, Maquiavel é enviado para observar o cenário. Tudo, porém, muda rapidamente nos meses seguintes e a Signoria de Florença envia tropas para a tomada da cidade. Quando surge a proposta de convocar uma consulta geral dos cidadãos de Pistoia, Maquiavel é mais uma vez chamado para averiguar a viabilidade de uma consulta pública selar um pacto político entre as facções. Dessa maneira, as análises empíricas e a ciência política aplicada de Maquiavel neste texto ajudam aprofundar seu tratamento de facções em outros textos.

\section{"Sobre a situação de Pistoia" (1502)}

O quarto texto, "Sobre a Situação de Pistoia" é um adendo ao texto anterior e analisa a conjuntura política da cidade e do campo para sugerir o desenho mais adequado de instituições políticas. Marchand (1975) argumenta que não

Príncipe, cap. XX (onde Maquiavel discorda do dito tradicional de que é necessário controlar Pistoia pela divisão interna e Pisa por fortalezas).

Discursos, capítulos IV (sobre o conflito entre facções no Senado e no qual Comunas de Roma explicam a sua grandeza), VII (e o direito de acusar para preservar a liberdade) e XXVII (sobre o erro de achar que dividir facilita o reinar).

- Os Panciatici são a facção de Pistoia no exílio. 
há provas da autoria de Maquiavel desse texto. Mas seguimos Montevecchi (2007, p. 34) no sentido de considerá-lo como complemento importante do texto anterior de Maquiavel sobre as facções em Pistoia e as propostas de reforma institucional. Neste texto, as expectativas do autor sobre as reformas fogem das dicotomias entre a força e os favores articulados no Príncipe e nos Discursos, que servem para caracterizar o maquiavelismo, um assunto que voltaremos a discutir abaixo.

\section{"Descrição do modo adotado pelo duque Valentino para matar Vitellozzo Vitegli, Oliverotto Pagolo e o duque de Gravina Orsini"} (1515-16)

O quinto texto, "Descrição do modo adotado pelo duque Valentino para matar Vitellozzo Vitegli, Oliverotto Pagolo e o duque de Gravina Orsini”, de 1515-16, narra os eventos de outubro de 1502 a janeiro de 1503 e coloca em destaque o brilho estratégico de César Bórgia ${ }^{7}$. Escrito treze anos depois do despacho de alerta citado logo a seguir, o fascínio de Maquiavel, já deposto do cargo de secretário depois do retorno de Lourenço de Médici em 1512, e a descrição detalhada do uso tático de tropas para culminar num ato amoral registra a combinação cruel de perversidade e inteligência em Maquiavel mais ainda, pela sua admiração por César Bórgia, líder político e militar da cadeia de reação que derrotou a república Florentina. Porém, César Bórgia é apresentado de modo diferente pelo Maquiavel no texto discutido a seguir.

\section{"Palavras que devem ser ditas sobre a provisão do dinheiro com um pouco de proêmio e de desculpas" (1503)}

O sexto texto, "Palavras que devem ser ditas sobre a provisão do dinheiro com um pouco de proêmio e de desculpas", é assinado por Maquiavel em "março de 1503" e trata da questão fiscal enfrentada por Piero Soderini depois de ser nomeado gonfaloniere vitalício em setembro de 1502. Os problemas fiscais surgem da necessidade de tributar fundos suficientes para contratar mercenários, pagar pela proteção ao rei de França e manter recursos para dissuadir eventuais ataques por cidades italianas e Estados estrangeiros. Essa pressão fiscal pelo cerco de César Bórgia sobre Toscana e Florença, que contava com apoio de seu pai, o papa Alexandre VI, como também do rei de 
França Luis XII, exacerbava conflitos políticos internos. A correspondência entre Soderini e Maquiavel (Marchand, 1975, p. 53) reflete a sua preocupação quanto aos cortes de salário de servidores públicos, ao peso de pagamentos recentes à Suíça, à incerteza da nova conjuntura política externa e à oposição no Conselho Maior às medidas de austeridade e à proposta de aumentar impostos. Em despacho de 1502, Maquiavel já alertara a Signoria e Soderini sobre o cerco da reação, citando um discurso de César Bórgia: "Este governo [republicano florentino] não me agrada e não posso confiar nele; portanto o mudarei" (Marchand, 1975, p. 55). Portanto, este texto aborda muito mais que dinheiro e questões fiscais. Aqui, Maquiavel prepara um apelo ao povo florentino para que aprove o novo tributo sobre propriedades eclesiásticas e abandone a ingenuidade de acreditar na proteção diplomática francesa diante da nova cadeia de reação monárquica:

E se replicardes: "Que necessidade há de forças militares? Estamos sob a proteção do rei [Luís XII, da França] e nossos inimigos estão liquidados! O Duque Valentino [César Bórgia] não tem motivo para nos atacar!” Poder-se-ia dizer-vos que tal opinião não poderia ser mais temerária. Porque todo Estado, toda cidade deve reputar inimigo todos aqueles que podem ter esperanças em poder ocupar o que é seu, e de quem eles não podem se defender. Nem houve jamais nem senhor, nem república sábios que quisessem manter seus Estados à discrição de outros, ou que assim mantendo-o lhes parecesse tê-los em segurança (Maquiavel, 2010, p. 51-2).

Portanto, este texto traz outro olhar sobre a relação entre Maquiavel e César Bórgia e apresenta sua economia - e sociologia - política sobre o fisco florentino. As questões fiscais e militares voltarão a ser foco de Maquiavel nos textos a seguir, depois do texto sobre a rebelião na cidade de Valdichiana.

\section{"Do modo de tratar os povos rebelados do Valdichiana" (1503)}

O sétimo texto, "Do Modo de Tratar os Povos Rebelados do Valdichiana", de 1503, resgata o juízo político clássico. Cita, nas palavras de Lívio, o discurso de Lúcio Camilo perante o Senado romano sobre o que fazer com os povos de Lácio depois da retomada pelas forças romanas e a supressão de revoltas. Surge novamente a questão colocada por Tucídides, que registrou o debate na ágora ateniense entre o demagogo Cleon e Diodotus sobre o que fazer com 
o povo de Mitilene. Nada mais renascentista que o apelo de Maquiavel às políticas de Roma, na cobrança cruel de evitar o tratamento igual e, portanto, ameno demais, para a cidade de Arezzo, em comparação as outras cidades toscanas: "Os romanos pensaram outrora que os povos rebelados devem ser ou beneficiados ou mortos, e que qualquer outro caminho seria perigosíssimo. A mim parece que aos aretinos vós não fizestes nenhuma das duas coisas..." (Maquiavel, 2010, p. 46). Aqui, Maquiavel antecipa sua fórmula para a decisão política, no capítulo XXIII dos Discursos, onde medidas pela metade são criticadas e, de duas, uma, aconselha: "ou ganhar-lhes a confiança com benefícios, ou tratá-las de maneira que nunca mais pudessem desafiá-los”.

Para Maquiavel, o avanço de César Bórgia sobre as cidades da Toscana incentivou revoltas em Pistoia (1501) e uma rebelião em Arezzo (1502), essas ameaçando espalhar-se por outras cidades. Como secretário da Chancelaria, Maquiavel acompanhou as operações aliadas francesas e visitou a cidade de Arezzo três vezes junto ao capitão Langres, líder das tropas francesas (Marchand, 1975, p. 100). Apesar da retomada de Arezzo e Valdichiana pelo rei Luís XII, durante essas duas missões diplomáticas Maquiavel percebeu a audácia militar de César Bórgia como também a astúcia das suas ordens para organizar politicamente cidades tomadas por Veneza e seus aliados. A análise de Maquiavel sugere uma navalha fina, e juízo empírico, entre realpolitik e uma sabedoria política para evitar a centralização excessiva do controle florentino sobre suas cidades vizinhas. Maquiavel, desta maneira, foge, neste texto, das dicotomias que tendem a dominar seus textos principais sobre a política. A política exterior de controle de Florença sobre cidades toscanas é temperada com a sociologia política das instituições políticas internas.

\section{"Discurso sobre a ordenação do Estado de Florença para as armas" (1506)}

O oitavo texto, "Discurso sobre a ordenação do Estado de Florença para as armas”, de 1506, volta à questão militar com mais um apelo aos cidadãos para não confiar em alianças nem na contratação de mercenários para defender a cidade, mas sim financiar uma força militar própria. ${ }^{8}$ Montevecchi

A crítica de Maquiavel ao uso de mercenários estrangeiros e a insistência em organizar tropas próprias permeia sua obra, desde seu despacho lamentando a desordem das tropas suíças e dos gascões por Florença, em 1500, para reprimir as revoltas em Pisa (Gilbert, 1986). 
sugere que o texto foi escrito para ajudar o gonfaloniere Piero Soderini a convencer os florentinos a aprovar um novo tributo sobre imóveis eclesiásticos (Montevecchi, 2007, p. 35). O motivo pode ser fiscal, mas o foco do discurso é a resistência dos cidadãos florentinos ao custo e ao envolvimento maior de uma força militar própria. Maquiavel denuncia novamente a ingenuidade dos florentinos em acreditar que a cidade era segura contra o avanço de César Bórgia pelo acordo feito com o rei de França, Luís XII. Ele insiste: é necessário aprofundar a justiça e mobilizar forças armadas próprias para preservar a liberdade: "[T] odos sabem que quem diz império, reino, principado, república, quem diz homens que comandam, começando do primeiro grau e descendo até o comandante de um bergantim, diz justiça e armas" (Maquiavel, 2010, p. 55, itálico adicionado).

Maquiavel também desce o nível de análise para um argumento sequencial. O alistamento e os treinamentos militares deveriam ser realizados primeiro no campo, segundo na cidade e, só no fim, nas cidades controladas por Florença. E, mesmo assim, é preciso evitar o armamento de outras cidades com fortalezas para evitar rebeliões. Aqui Maquiavel combina sociologia e psicologia militar para propor um sequenciamento capaz de reverter a realidade de líderes inadequados e corruptos para mobilizar a participação militar cidadã e assegurar a liberdade externa.

\section{“Provisões da República de Florença para instituir o Magistrado dos Nove Oficiais da Ordenança e Milícia Florentina" (1506)}

O nono texto, "Provisões da República de Florença para instituir o Magistrado dos Nove Oficiais da Ordenança e Milícia Florentina”, apresenta a reforma das forças armadas de Florença como projeto de lei encaminhado oficialmente em 30 de novembro de 1506 e aprovado pelo Conselho Maior em 6 de dezembro, com 841 votos a favor e 317 contra. É a maior vitória política de Maquiavel e a sua teoria sobre a importância do serviço militar. A organização de forças armadas é uma questão de sociologia política, não técnica. A "conjugação orgânica” (Montevecchi, 2007, p. 38) da questão de justiça com a questão de armas por Maquiavel é uma revolução sobre visões antigas das comunas medievais, como também as soluções das oligarquias antigas e da nova burguesia, ou seja, de simplesmente contratar mercenários: 
E tendo conhecido por uma longa experiência, ainda que com grande prejuízo e perigo, quão pouca confiança se pode ter nos soldados estrangeiros e mercenários, pois se são numerosos e estimados, são insuportáveis ou suspeitos, e se são poucos ou não estimados não são de nenhuma utilidade, julgai ser um bem se armar de armas próprias e com seus próprios homens, dos quais vossos domínios são copiosos, de maneira que facilmente se poderá ter o número de homens bem qualificados que se quererá (Maquiavel, 2010, p. 59).

Para Maquiavel, a organização de forças armadas próprias é fundamental para a liberdade republicana interna e a independência externa perante os Estados territoriais novos e cidades vizinhas em expansão.

É uma ironia do destino que esse novo ordenamento militar redigido por Maquiavel tenha sido introduzido em 1514, ou seja, dois anos depois do fim da república e do seu afastamento do serviço público pelo governo de Lourenço de Médici. Mesmo assim, a aprovação da reforma militar de Maquiavel representa uma raridade: a aceitação de uma teoria política inovadora em processo decisório republicano, ou seja, na votação em 1506. Nesse sentido, este texto apresenta novas perspectivas para responder à pergunta de Sasso: "A qual extrato social dirigem-se as reformas de Maquiavel?” (Sasso apud Montevecchi, 2007, p. 38). Essa pergunta capta, retroativamente, a posição de Rousseau sobre Maquiavel (McKenzie, 1982) como também os agudos paralelos de Lefort (2003) entre Maquiavel, Marx e Gramsci (Martuscelli, 2008).

\section{"Parecer para a eleição do capitão das Infantarias da Ordenança Florentina" (1511), "Escrito sobre o modo de reconstruir a Ordenança" (1515)}

O décimo texto, "Parecer para a eleição do capitão das Infantarias da Ordenança Florentina", de 1511, e o décimo primeiro texto, "Escrito sobre o modo de reconstruir a Ordenança", de 1515, complementam o projeto de reforma e discussão anterior de Maquiavel sobre armas. O primeiro focaliza a questão da liderança, e o segundo focaliza questões relacionadas à desmobilização de tropas. Os dois mantêm a conjugação orgânica entre justiça e armas. Maquiavel trata da organização militar como uma questão de sociologia política, mostrando como a estrutura social de Florença deveria ser a base para o processo eleitoral para selecionar capitães para as infantarias. 


\section{Textos menores sobre a França e a Alemanha: “Da natureza dos gauleses" (1501), “Nótula para alguém que será embaixador em França" (1504)}

Os textos de Maquiavel sobre a França são redações ligadas às suas missões diplomáticas realizadas para a Chancelaria de Florença. "Da natureza dos gauleses” foi escrito durante a primeira viagem de Maquiavel, em 1500, e ampliado no ano seguinte. A "Nótula para alguém que será embaixador em França” foi escrito em 1504, com a missão de levar novas instruções para o embaixador Valori de Florença em Paris. Depois da derrota da França diante das forças espanholas na batalha de Garigliano, Maquiavel assiste às negociações em fevereiro e março em Paris. Villari e Tommassini discordam sobre a data de redação do "Retrato das coisas de França" (Marchand, 1975, p. 260). Mas este texto provavelmente foi escrito em 1510 e aumentado em 1511, depois da terceira missão diplomática de Maquiavel na França, dessa vez entre junho e outubro, para propor a mediação de Florença para um acordo de paz entre as duas potências, a França e a Espanha.

O texto "Da natureza dos gauleses" apresenta observações enxutas sobre o caráter e o comportamento dos franceses. A "Nótula para alguém que será embaixador em França" descreve o protocolo e as maneiras mais adequadas para um diplomata na corte francesa. Enquanto, para Dupré-Theseider e Marchand, a banalidade do segundo texto coloca em dúvida a autoria de Maquiavel, acatamos o juízo contrário de Montevecchi (2007, p. 40), pelo valor da descrição de hábitos no Estado francês emergente. Em o "Retrato das coisas de França”, Maquiavel explica a estrutura do Estado francês citando causas institucionais e políticas, como as regras de herança, a transformação dos vizinhos em súditos e a primogenitura combinada com a tradição de que os outros filhos conquistem territórios para estender domínios:

A Coroa e os reis da França são hoje mais fortes e ricos e mais poderosos do que nunca... A Coroa, transmitida por sucessão hereditária, tornou-se rica porque sempre que o rei não tinha filhos, nem ninguém que lhe sucedesse em sua herança, as riquezas, os domínios e os bens do rei ficaram com a ela (Maquiavel, 2010, p. 85).

Para Maquiavel, a consolidação da coroa e do Estado francês se deve também pelos princípios de sangue e de descendência dinástica: "Assim, se não houver ninguém superior ou anterior a eles na linhagem, a Coroa 
pode vir a ser de algum deles. Por isso todos se mantêm unidos à Coroa, na expectativa de que eles, ou seus filhos, possam alcançá-la” (Maquiavel, 2010, p. 85). Maquiavel também contrasta a primogenitura e a tradição de conquistar terras para a coroa na França com situações mais ambíguas na Alemanha e na Itália:

Há uma última razão para o grande poder francês, e é a seguinte. Os domínios dos barões da França não são divididos entre seus herdeiros, como se faz na Alemanha e em muitas partes da Itália, mas vão sempre para os primogênitos, que são os verdadeiros herdeiros. Os outros irmãos têm que se resignar e, ajudados pelo irmão primogênito, se dedicam todos às armas e se empenham nessa arte para alcançar uma condição que lhes permita conquistar um domínio, e com essa esperança se nutrem. E é por isso que a cavalaria pesada francesa é a melhor que existe, porque nela se encontram todos os nobres e filhos de senhores, e estão prontos e dispostos a se tornarem senhores (Maquiavel, 2010, p. 86).

Ao contrário do feudalismo caótico que impede o surgimento de um Estado territorial mais centralizado na Alemanha e na Itália, Maquiavel enfatiza a abertura da coroa francesa para os chefes feudais regionais como explicação chave. A seguir, Maquiavel descreve a riqueza agrícola e eclesiástica na França, apresenta um sumário das suas políticas exteriores, combina análises sociais e geopolíticas, descreve nuances da base orçamentária, fiscal e financeira e termina com uma discussão sobre a organização da guarda pessoal do rei para explicar as pretensões da França na Itália. Portanto, aqui Maquiavel desvenda as estruturas de um Estado moderno emergente, centralizado e mais capaz de defender seus territórios.

\section{"Discurso sobre as coisas da Alemanha e sobre o imperador" (1508-9), "Retrato sobre as coisas da Alemanha" (1512)}

Estes textos de Maquiavel sobre a Alemanha aprofundam a análise dele sobre o surgimento do Estado moderno. Existem duas versões do "Discurso sobre as coisas da Alemanha e sobre o imperador" (1508-9) mais o "Retrato sobre as coisas da Alemanha" (1512). Estes textos também surgem das suas atividades diplomáticas na Chancelaria. São escritos depois da Dieta de Constança e retratam a Alemanha, seu imperador e a atuação política da República Sagrada Romana. O primeiro "Discurso sobre as coisas da Alemanha 
e sobre o imperador" foi escrito ao longo de 1508, segundo o relato entregue por Maquiavel a Piero Soderini, mesmo participando em cargo diplomático secundário. A segunda versão desse discurso foi ampliada durante 1509 para Giovanvittorio Soderini e Piero Guicciardini.

O terceiro texto, "Retrato sobre as coisas da Alemanha", é uma ampliação do relatório de Maquiavel sobre sua missão na Alemanha e foi escrito em 1512, inclusive repetindo trechos do texto original. Maquiavel foi enviado para a Alemanha para averiguar o sucesso do imperador Maximiliano em levantar o número de tropas para entrar na Itália como concordado com seus súditos na Dieta de Constança em agosto de 1507. Eis outra dimensão de incursão estrangeira na Itália: casado em 1494 com Bianca Maria Sforza, filha do duque de Milão, o imperador Maximiliano sonhava ser coroado imperador da Sagrada República Romana agora uma segunda vez pelo papa em Roma. Isso explica, em parte, a invasão de Nápoles, em 1494, pelo rei de França Carlos VIII. Aparências à parte, e apesar de reformas em 1495, na Dieta de Worms, Maquiavel enfatiza a incapacidade do imperador de tributar e de mobilizar forças armadas, apesar das reafirmações de Maximiliano na Dieta de Constança em 1507:

[O imperador Maximiliano] é o homem mais dissipador de seu patrimônio do que qualquer um do nosso tempo ou que existiu no passado. (...) É volúvel, porque hoje quer uma coisa e amanhã não a quer, não se aconselha com ninguém e acredita em todos, que as coisas que não pode ter e daquelas que pode ter se afasta, e por isso toma sempre a decisão contrária àquela que deveria (Maquiavel, 2010, p. 95).

Mas Maquiavel vai além da personalidade de Maximiliano e, resumindo os empecilhos contra a centralização do Estado na Alemanha pela comparação negativa, aprofunda sua explicação do surgimento do Estado moderno.

Em Florença, os cálculos de Maquiavel caíam num contexto político interno avesso. É certo que o quadro para Maximiliano melhorou em 1507, pois a relação entre a França e o rei de Aragão estremecia relações na Espanha. Maquiavel é nomeado no dia 19 de junho pelo gonfaloniere Piero Soderini para averiguar o risco de invasão e, em caso de ser real, calcular e sondar o valor de pagamento necessário para uma solução diplomática. Esse cálculo de política externa exacerba a disputa entre Soderini e as forças oligárquicas florentinas. No dia 25 de junho, Francesco di Piero Vettori é eleito pelo 
Conselho Maior para substituir Maquiavel na missão diplomática, uma derrota para Soderini e Maquiavel. Desde 1494, apesar dos acordos entre a república florentina e a França, a oligarquia procurava aliar-se com Maximiliano. Daí a superestimação de Vettori sobre as forças armadas mobilizadas pelo imperador. Era alarmismo puro que visava mudar a política florentina externa, da França para o Império e, pelo medo, mudar a política interna da república para outro governo e regime (Rubenstein, 1957).

Os textos de Maquiavel sobre a Alemanha se inserem nessa disputa entre forças republicanas e a reação oligárquica em Florença. Maquiavel procura evitar a instilação do medo diante das forças imperais: Vettori atestou haver cinquenta mil homens armados por Maximiliano; Maquiavel, ao contrário, descreve a incapacidade de Maximiliano em fazer valerem as promessas extraídas na Dieta de Constança:

[P]ensam que não há na Alemanha nenhum príncipe que pudesse ou ousasse opor-se aos planos do imperador, como eles costumavam fazer até pouco tempo atrás, todavia não pensam que a um imperador seja um obstáculo muito grande não ter a ajuda dos príncipes nos seus planos. Porque quem não ousa mover guerra contra ele, ousa negar-lhe ajuda. E quem não ousa negar-lhe ajuda ousa, mesmo prometendo-lhe, não manter a promessa. E mesmo quem não ousa não manter a promessa para com o imperador, ousa ainda adiá-la e tal maneira que não lhe são mais de valia. E tudo isso impede e atrapalha os planos do imperador (...)

E percebeu-se que isso é verdade quando ao imperador, na primeira vez que quis descer para a Itália contra a vontade dos venezianos e dos franceses, foi lhe prometido pelas comunas da Alemanha, na Dieta que aconteceu em Constança, dezenove mil infantes e três mil cavaleiros, e nunca se conseguiu reunir mais do que cinco mil soldados (Maquiavel, 2010, p. 98).

Aqui Maquiavel amplia a sua comparação entre o Estado francês e o caos feudal na Alemanha, para salientar a sua preocupação maior, ou seja, a Itália. Nesse empreendimento, volta novamente aos clássicos, desta vez à Germania de Tacitus. Repete sua análise consagrada da estrutura tribal por trás dos feudos, das comunas e das forças armadas alemãs e assim confirma as causas do surgimento do Estado moderno na França. Para Maquiavel, esse subdesenvolvimento político é paradoxal perante a riqueza e as virtudes militares da Alemanha. 


\section{Os textos menores de Maquiavel sobre política fora do poder: "Aos Palleschi: atentem bem para este escrito" (1512)}

O quarto grupo de textos contem cinco escritos de Maquiavel depois do fim do governo republicano e de seu afastamento do serviço público em 1512. O texto "Aos Palleschi: atentem bem para este escrito" é um apelo feito por Maquiavel em 1512 para evitar a desmoralização de Piero Soderini depois da sua saída e fuga perante a oligarquia:

Eu quero advertir-vos sobre a opinião daqueles que dizem como seria bom mostrar a todos os defeitos de Pie ${ }^{\text {tro }}$ Soderini para diminuir a sua reputação junto ao povo, e para que vós olheis esses bem no rosto e considereis o que os move. E vereis como não lhes move o bem deste regime político, mas sim a reputação de si próprios (Maquiavel, 2010, p. 109).

Maquiavel retrata a conjuntura que pairou sobre Florença depois da retirada de tropas francesas da Itália no meio do cerco das forças antirrepublicanas. O texto é datado por Marchand justamente dias antes da dispensa de Maquiavel da Chancelaria, em 7 de novembro de 1512, e a ordem de prisão domiciliar que ele sofre três dias depois. Portanto, o texto é a última tentativa oficial de Maquiavel influenciar a construção do novo regime.

O contexto político deste texto é composto, de um lado, por uma tentativa de volta das forças republicanas pela formação de uma Balía (assembleia) e, do outro lado, um golpe militar e a chegada dos Médici. A saída das tropas francesas da Itália em 1512 deixara Florença à mercê do papa e de seus aliados Veneza, Milão e Espanha. A hesitação de Florença em participar da Santa Liga na fase final da guerra selara o fim da república. E, quando o Congresso de Mantova cede a cidade aos Médici e tropas espanholas a caminho de Florença saqueiam a cidade toscana de Prato, matando cinquenta mil residentes nas ruas, Florença se rende e o gonfaloniere Piero Soderini foge, no dia de 31 de agosto. Segue-se um período de incerteza com a eleição de Giovanbattista Ridolfi (republicano que apoiou Savonarola) gonfaloniere no dia $1^{\circ}$ de setembro, seguida, em 16 de setembro, por um golpe de Estado por tropas espanholas lideradas pelo cardeal Giovanni de Médici. Enquanto isso, o popoli maggiore ainda elege uma Balía encarregada de apresentar reformas pela recuperação das estruturas políticas mais republicanas da época de Médici. 
Portanto, através deste texto, Maquiavel tenta triar algumas facções de Palleschi (apoiadores dos Médici) da reação oligárquica e monárquica. Longe de ser uma figura prestes a ser agraciada pelos Médici (inferência pela dedicação do Príncipe ao Lourenço), que neste momento acumulavam apoios externos - eclesiástico e militar - para domar a cidade, este texto de Maquiavel aponta para a autonomia da política, mesmo sendo uma janela limitada durante o fechamento de um regime de reação. Nosso servidor público tenta evitar a destruição das forças republicanas pela vingança. $\mathrm{O}$ seu argumento separa níveis de análise que hoje descreveríamos com os conceitos de Estado, regime e governo. Como republicano, perdeu o Estado e o regime. Sobrou para Maquiavel tentar evitar uma escalada vingativa no novo governo, mesmo que isso implicasse adotar uma narrativa aparentemente antirrepublicana. Dessa maneira, ele argumenta que os propagandistas anti Soderini apresentavam riscos para a consolidação do governo Médici e a organização de um novo regime:

[E]ste regime não tem por inimigo Piero Soderini, mas sim a república, e por isso seria necessário, para ajudá-lo, falar mal da república, não de Piero. Mas alguns cidadãos, sobretudo esses que denigrem entre o povo também os Médici, têm por inimigo Piero, e gostariam de denegri-lo para se livrarem da antipatia popular por terem hostilizado Soderini. O que se é favorável a eles próprios, não é para os Médici, nem para quem quer ficar com eles, no bem e no mal (Maquiavel, 2010, p. 109).

Estranhamos que Montevecchi insista que este texto ficou marginal à história. Para Montevecchi (2007, p. 43), os Médici mantinham todos os recursos necessários para, de um lado, controlar uma reação oligárquica e, de outro, enquadrar o povo florentino. Em retrospecto, as janelas de oportunidade e as opções durante um momento político tendem a desaparecer. Mas, como este texto está entre os últimos escritos por Maquiavel como servidor público, talvez convenha lê-lo pela clareza analítica sobre o momento político antes de descartá-lo pela sua marginalidade histórica.

\section{"Alocação feita a um magistrado" (1519)}

O décimo oitavo texto, “Alocação Feita a um Magistrado", de 1519, é uma redação renascentista exemplar que registra Maquiavel se defendendo, já afastado do serviço público. Não sabemos quem era o magistrado, nem a razão da convocação de Maquiavel perante essas autoridades sete anos de- 
pois do afastamento de seu cargo na chancelaria. Mas as referências à justiça (genéricas) como base da ordem e da ação política, e as citações de Ovídio, Virgilio, Trajano e Dante exemplificam um Maquiavel renascentista. O trecho da Divina comédia reproduzido por Maquiavel é a história da salvação de Trajano por são Gregório, indicando que a incerteza política depois de sua saída de serviço público tinha uma dimensão kafkiana para Maquiavel.

\section{"Sumário do governo da cidade de Lucca" (1520)}

O vigésimo texto, "Sumário do governo da cidade de Lucca", de 1520, hoje seria chamado uma análise de risco político. Foi escrito para um grupo de empresários florentinos depois da bancarrota do banco de Michele Guinigi. Maquiavel aqui aprofunda sua análise de sociologia política das instituições de uma cidade-Estado menor. O republicanismo de Maquiavel ainda sobressai, pois as três instituições de gonfaloniere, Senhoria e Conselho Geral representam, de certa maneira, em paralelo com o Capítulo X dos Discursos, uma ponte renascentista entre a teoria clássica da constituição mista, exemplificada por Políbio, e a teoria liberal da separação dos poderes e freios e contrapesos que surgirá no século XVIII. O detalhamento dos processos eleitorais para cargos, e de banimento de cidadãos, e a anotação de divergências necessárias de boas práticas republicanas devido à escala menor da cidade de Lucca, antecede sua conclusão "protofederalista”. Pois, para Maquiavel, em repúblicas, "é muito mais perigoso nela o sim que o não, e que é mais necessário conter aqueles que querem que se faça algo do que aqueles que não querem que se faça" (Maquiavel, 2010, p. 107).

\section{"Discurso florentino em memória a Lourenço de Médici" (1520)}

O "Discurso florentino em memória ao Lourenço de Médici", de 1520 (publicado em edições anteriores como "Discurso sobre a reforma do Estado de Florença para Leo X”), aprofunda o cálculo político pós-república de Maquiavel sobre a Florença. Depois da morte de Lourenço de Médici, aos 27 anos de idade, em 1519, surgiu novamente a indefinição política que já foi objeto de análise de Maquiavel em "Aos Palleschi", de 1512. Outra vez, o cardeal (e futuro papa Clemente VII) Giulio de Médici se envolve na política florentina e evita a liquidação da Signoria. Dessa maneira, neste texto, escrito oito anos depois do fim da república, Maquiavel novamente calcula o "menos mal" para tentar evitar a consolidação de um governo autocrático. 
Para Montevecchi, o motivo desta memória a Lourenço de Médici é o de enfatizar "a fraqueza congênita do Estado florentino, a necessidade de reforçar as estruturas da comuna e de reduzir o poder das castas e dos grupos privados" (Montevecchi, 2007, p. 44). Rubenstein confirma esse motivo quando abre sua introdução à coletânea sobre Maquiavel e o republicanismo, citando a primeira frase desta memória de Maquiavel: "A razão pela qual Florença sempre mudou com frequência seus governos está no fato de que nela nunca houve nem república, nem principado, que tenham tido suas devidas qualidades" (Rubenstein, 1990, p. 3). Aqui, Maquiavel declara que Florença nunca foi, realmente, uma república sob os Médici. Assim, nem principado, nem república e, sim, dominação oligárquica.

Portanto, este texto retrata empiricamente uma transição política mais ambígua e evita insistir em dicotomias definitivas entre as duas formas de governo - república e principado - como ocorre frequentemente nos capítulos do Príncipe e dos Discursos. Em contraste a esses textos maiores sobre a política, aqui Maquiavel adota uma análise de tendências, de duas, uma, ao nível de regime político:

O principado só tem uma via para a sua dissolução, que é descer rumo a uma república; e a república só tem um caminho para a sua dissolução, que é subir rumo ao principado. Os regimes que estão no meio deles têm dois caminhos: ou ascender em direção ao principado, ou descer em direção à república (Maquiavel, 2010, p. 120).

Essa lógica dual de mudança política informa a tentativa de Maquiavel de evitar a deterioração da situação dos Médici em 1520 e, dessa maneira, abrir um caminho possível rumo a uma república. Mas, para Maquiavel, mudanças entre regimes implicam também uma sociologia política, no sentido de reconhecer a igualdade e a desigualdade como bases de principados e repúblicas:

[E]m toda cidade em que há grande igualdade entre os cidadãos não se pode estabelecer um principado, a não ser com a máxima dificuldade; e naquelas cidades nas quais há uma grande desigualdade entre os cidadãos não se pode instituir uma república. Porque para criar uma república em Milão, onde há grande desigualdade entre os cidadãos, seria necessário extinguir toda a nobreza, e reduzi-la à igualdade com os outros, porque entre eles há tantas diferenças que as leis não bastam para reprimi-las, mas é preciso uma voz forte e uma autoridade régia que as reprima. E, ao contrário, para se instituir um principado em Florença, onde há uma grandíssima igualdade, é 
preciso antes estabelecer a desigualdade, e criar muitos nobres de castelos e vilarejos, os quais, juntamente com o príncipe, submetessem com as armas e com o apoio deles [o príncipe] mantivesse subjugada a cidade e toda a província (Maquiavel, 2010, p. 120).

Embora longa, a citação que segue esclarece a ligação entre a lógica dual de mudança política e as bases sociais que Maquiavel utiliza para tentar convencer o papa Leo X das vantagens de uma república, agora neste momento para a segurança dos Médici e de seu extrato social:

Mas porque fazer um principado onde assentaria bem uma república, e uma república onde assentaria bem um principado é coisa difícil, inumana e indigna de qualquer um que queira ser considerado piedoso e bom, eu não tratarei do principado, e sim da república; seja porque Florença está muito bem disposta para tomar essa forma [de governo]; seja porque se percebe que Vossa Santidade está disposta a implantá-la, e se acredita que Vossa Santidade adie essa realização porque deseja encontrar um modo de manter grande sua autoridade em Florença, e garantir que seus amigos aí vivam seguros. E parecendo ter excogitado esse modo, quis que Vossa Santidade ouvisse esse meu pensamento para que, se há algo de bom nele, possa se servir dele, e por meio dele possa conhecer qual é minha serventia para com a Vossa Santidade. E verá como nessa minha república o seu poder não só se mantém, mas aumenta, e seus aliados nela permanecerão honrados e seguros, e todos os outros cidadãos terão evidentes motivos para se contentarem (Maquiavel, 2010, p. 120).

Apesar de ser chamado utópico por Montevecchi (2007, p. 44), esse apelo de Maquiavel ao papa Leo X aparentemente foi endossado pelo cardeal Giulio de Médici. ${ }^{9}$ Pensamos no consenso sobre a tendência unívoca da política de

9 A comparação de Maquiavel entre o regime anterior dos Médici e o momento atual para este fim é notável: "Antes de qualquer coisa, aquele regime tinha o apoio do povo, e este tem o povo como inimigo. Os cidadãos daquele tempo nunca tinham vivido sob um regime político que parecesse mais largo [com participação mais amplo] do que aquele. Os cidadãos de agora já conheceram outro que Ihes parece mais largo e no qual estão mais contentes. Na Itália, então, não havia nem exércitos, nem potências que os florentinos não pudessem, mesmo sozinhos, enfrentar. Agora, como a Espanha e a França encontram-se na Itália, convém aos florentinos serem amigos de uma delas e, se a aliada perder, logo ficarão à mercê dos vencedores, o que então não acontecia. Antes os cidadãos estavam costumados a pagar taxas; agora, ou por impotência ou por ter perdido o costume, estão desacostumados. Os Médici que então governavam, por terem sido nutridos e criados com seus cidadãos, comportavam com tanta familiaridade que isso os ajudava. Agora, são tão poderosos que se tornaram estranhos à vida dos cidadãos florentinos, não pode mais haver aquela intimidade e, por conseguinte, aquele apoio popular. Assim sendo, considerando essas diferenças entre os tempos e os homens, não pode haver maiôs engano do que acreditar, em meio a tantas diferenças de matéria, restabelecer a mesma forma [de governo]. Nem se acredite ser verdadeiro que os homens facilmente 
tender para formas de governo, ou autocrático, ou democrático, seja pelo conceito de "poder dual", na tradição marxista que vai de Lênin a Rosa Luxemburgo, seja na dicotomia de Carl Friedrich e Zbigniew Brzezinski entre totalitarismo e democracia. Desse ponto de vista, esta memória de Maquiavel a Lourenço de Médici vale especialmente para a ciência política em situações mais ambíguas, como frequentemente tem sido a experiência brasileira entre a democracia e o autoritarismo. Nesse sentido, a ambiguidade política de Florença em 1520, como contexto de atuação de Maquiavel como ex-servidor público, é mais próxima das situações repetidamente não resolvidas no Brasil. A forma de governo monárquica mais clara encontrada por Maquiavel, na França, na Espanha e mesmo na Alemanha, contrasta com a irresolução da política em Florença. Mesmo depois do fim da república, os contornos do regime e dos governos sob os Médici exemplificam essa situação mais complexa e fluida, onde as tentativas de assegurar o menos mal de Maquiavel são descritas. Portanto, Maquiavel registra mais um momento político nesta memória para Lourenço de Médici. Ele aponta onde e como a autonomia da política poderia servir aos valores republicanos, pelo redesenho de instituições mais adequadas à estrutura social da Florença. Maquiavel permanece republicano perante o papa Leo X em 1520.

\section{"Memorial a Raffaello Girolami, quando no dia 23 de outubro partiu para a Espanha [como Embaixador junto ao] imperador" (1522)}

O "Memorial a Raffaello Girolami” foi escrito em 1522. Aqui Maquiavel não só lembra seu serviço diplomático e descreve a importância da ética de registrar informações detalhadas sobre o governo da Espanha como também oferece instruções sobre como construir cenários futuros mais prováveis. Aqui Maquiavel combina preocupações de ética no exercício de funções de serviço público com a metodologia de ciência política mais adequada para forecasting. Termina listando uma série de informações a serem levantadas para esclarecer a política interna e externa espanhola. Neste texto, o gênero de trabalho diplomático também ajuda a completar sua análise do Estado moderno emergente.

voltam ao antigo e costumeiro modo de viver, porque isso acontece quando o modo de vida antigo agrada mais do que o novo, mas quando agrada menos ele só volta ao antigo modo forçado, e nele se conforma enquanto durar a força que o obriga" (Maquiavel, 2010, p. 119). 


\section{Os textos menores sobre os muros de Florença: "Relação de uma visita feita para fortificar Florença" (1526), "Provisão para a instituição do cargo dos cinco provedores dos muros da cidade de Florença" (1526-27)}

Finalmente, há uma coda terrível de dois textos menores sobre a política de Maquiavel que tratam da manutenção e defesa dos muros de Florença. O texto "Relação de uma visita feita para fortificar Florença", de 1526, foi encomendado por Giulio de Médici já como papa Clemente VII, novamente selando uma relação política com Maquiavel. Não vemos oportunismo nem mudança de posição de nosso ex-servidor público notoriamente crítico e antagonista da Igreja e do papa. Pois, numa comparação mais ampla, e utilizando a expressão famosa de Mao Tse-Tung, a contradição principal no momento político italiano era nacional, não de classes ou de formas de governo. Se os comunistas na China fecharam com os nacionalistas, mesmo depois do massacre de Xangai, da mesma forma, a aceitação por Maquiavel do convite do papa Clemente VII, diante da chegada do exército espanhol e de mercenários alemães, não destoa nem invalida seu republicanismo. O vigésimo quarto e último texto, "Provisão para a instituição do cargo dos cinco provedores dos muros da cidade de Florença”, de 1526-7, continua o trabalho sóbrio de Maquiavel, dessa vez com uma proposta de estrutura de cargos que possa ajudar a manter e reorientar a posição dos muros, agora em condições ainda menos favoráveis.

\section{Conclusão}

Este artigo aponta para uma atenção maior aos textos menores de Maquiavel sobre a política, que só recentemente foram traduzidos para português como um conjunto mais completo (Maquiavel, 2010). Nossa breve discussão de vinte e quatro desses textos já indica a importância dessas análises empíricas de Maquiavel escritas para aconselhar ações políticas internas e externas. Sua leitura confirma a tendência nas últimas décadas de enfatizar o republicanismo de Maquiavel e revela uma ciência política aplicada que complementa suas obras maiores, como o Príncipe, os Discursos e a Arte da guerra, mesmo quinhentos anos depois da sua redação. Trabalhos históricos e filológicos sobre esses textos menores deixam mais claro como Maquiavel sempre visava servir à república florentina e aos valores republicanos, enquanto secretário da Chancelaria de Florença e também depois de seu afastamento, em 1512, com o fim da república florentina. Esses textos apresentam novas possibilidades de pesquisa e de 
reflexão sobre Maquiavel e sugerem que outros textos deixados de seu serviço em legazioni e commissarie (Bertelli, 1964) ainda possam servir para aprofundar estudos sobre o autor, uma conclusão incrível depois de meio milênio.

Os textos menores de Maquiavel sobre a política variam. O primeiro, de 1494, começa com a audácia militar a favor da retomada de Pisa de um Maquiavel recém-ingresso no serviço público da república florentina. $\mathrm{O}$ último, de 1526-7, encara o iminente saque de Florença por tropas e mercenários estrangeiros. Mas, apesar dessas diferenças de data e de contexto, 0 conjunto desses vinte e quatro textos sobre a política aqui analisados revela um Maquiavel republicano, servidor público e mestre em apontar o momento político, seja para a política exterior florentina, seja depois de seu afastamento na procura de males menores no meio de forças monárquicas, estrangeiras e papais enquanto os Médici retomavam a sua cidade. Os textos menores de Maquiavel sobre política, um tanto desprezados no Brasil, merecem destaque como fontes que podem esclarecer a ciência política e o republicanismo dele como também ajudar a superar entraves de interpretação ainda encontrados por leitores de suas obras maiores.

\section{Referências}

AMES, José L. (2002). Maquiavel: a lógica da ação política. Cascavel: Edunioeste.

BALL, Terence (1994). Reappraising political theory: revisionist studies in the history of political thought. Oxford: Oxford University Press.

BARON, Hans (1961). "Machiavelli: republican citizen”. English History Review, v. 76, n. 299, p. 217-53.

BERLIN, Isaiah (1997). "The originality of Machiavelli", em Against the current. Nova York: Viking Press.

BERTELLI, Sergio (org.) (1964). Legazioni e commissarie. 3 vols. Milão: Feltrinelli.

BOCK, Gisela; SKINNER, Quentin \& VIROLI, Maurizio (eds.) (1990). Machiavellianism and republicanism. Princeton: Princeton University Press. CHAUI, Marilena (2000). “Maquiavel”, em Filosofia. São Paulo: Ática.

CHISHOLM, Robert (1998). "A ética feroz de Nicolau Maquiavel” em QUIRINO, Célia G; VOUGA, Claudio \& BRANDÃO, Gildo M. (orgs.). Clássicos do pensamento político. São Paulo: Edusp.

CROCE, Benedetto (1925). Elementi di politica. Bari: Laterza e Figli. 
FALCO, Giorgio (1954). La santa romana repubblica. Milão: Riccardo Ricciardi.

FALCO, Maria J. (2004). Feminist interpretations of Niccoló Machiavelli. University Park: Penn State University Press.

GILBERT, Felix (1965). Machiavelli and Guicciardini. Princeton: Princeton University Press.

(1986). “Machiavelli: the Renaissance art of war", em PARET, Peter (ed.). The makers of modern strategy. Princeton: Princeton University Press.

GODMAN, Peter. (1998). From Poliziano to Machiavelli: Florentine humanism in the high Renaissance. Princeton: Princeton University Press.

GUIDI, Andrea (2009). Un segretario militante: politica, diplomacia e armi nel cancelliere Machiavelli. Bolonha: Mulin.

LEFORT, Claude (2003). "A primeira figura da filosofia da práxis: uma interpretação de Antonio Gramsci” em QUIRINO, Célia G. \& SADEK, Maria T. (orgs.). O pensamento político clássico. São Paulo: Martins Fontes. MACHIAVELLI, Niccolò (1852). Opere minori. Edição de Filippo Polidori. Florença: F. Le Monnier.

(1961). L'Arte della guerra e scritti politici minori. Edição de Sergio Bertelli. Milão: Feltrinelli.

(2007). Opere. 3 vols. Edição de Rinaldo Rinaldi e Alessandro Montevecchi. Turim: UTET.

MANSFIELD, Harvey (1996). Machiavelli's virtue. Chicago: University of Chicago Press.

MAQUIAVEL, Nicolau (2010). Maquiavel: política e gestão florentina. São Paulo: Fundação Getúlio Vargas.

MARCHAND, Jean Jacques (1975). Niccolò Machiavelli: i primi stritti politico (1499-

1512); nascita di un pensiero e di uno stile. Pádua: Antenore.

MARTUSCELLI, Danilo E. (2008). "Gramsci e Althusser como críticos de Maquiavel”. Revista de Sociologia Política, v. 16, n. suplementar, p. 27-41. MCCORMICK, John P. (2011). Machiavellian democracy. Cambridge: Cambridge University Press.

MCKENZIE, Lionel (1982). "Rousseau's debate with Machiavelli in the social contract". Journal of the History of Ideas, v. 43, n. 2, p. 209-228.

MEINECKE, Friedrich. (1957). The doctrine of raison d'Etat and its place 
in modern history. Machiavellianism. New Haven: Yale University Press. MONTEVECCHI, Alessandro (2007). "Nota storica”, em MACHIAVELLI, Niccolò. Opere. 3 vols. Turim: UTET.

PITKIN, Hannah (1984). Fortune is a woman: gender and politics in the thought of Niccolò Machiavelli. Chicago: University of Chicago Press. PLAMENATZ, John (1972). "In search of Machiavellian virtù", em PAREL, Anthony (ed.). The political calculus: essays on Machiavelli's philosophy. Toronto: University of Toronto Press.

POCKOCK, John (1975). The Machiavellian moment: florentine political thought and the Atlantic republican tradition. Princeton: Princeton University Press.

RAWLS, John (1985). "Justice as fairness: political not metaphysical". Philosophy \& Public Affairs, v. 14, n. 3, p. 223-251.

RIDOLFI, Roberto (2003). Biografia de Nicolau Maquiavel. São Paulo: Musa. RUBENSTEIN, Nicolai (1957). "The place of the empire in fifteenth-century Florentine political opinion and diplomacy". Bulletin of the Institute of Historical Research, n. 30, p. 125-135.

(1990). "Machiavelli and Florentine republican experience", em BOCK, Gisela; SKINNER, Quentin \& VIROLI, Maurizio (eds.). Machiavellianism and republicanism. Princeton: Princeton University Press. SABATINI, Rafael (1946). César Borgia. Rio de Janeiro: Vecchi.

SASSO, Gennaro (1966). Machiavelli e Cesare Borgia: storia de um giudizio. Roma: Ateneo.

SCOTT, John T. \& SULLIVAN, Vickie B. (1994). "Patricide and the plot of the Prince: César Bórgia and Machiavelli's Italy". American Political Science Review, v. 88, n. 4, p. 887-900.

SILVA, Walter F. L. (2012). Maquiavel segretario (1498-1512): guerra e política em I primi scritti politici. Dissertação (Mestrado em Filosofia) - PUC, São Paulo.

SKINNER, Quentin (1981). Machiavelli. Oxford: Oxford University Press.

STRAUSS, Leo (1958). Thoughts on Machiavelli. Chicago: University of Chicago Press.

VALVERDE, Antonio J. R. (2010). "Maquiavel a cavalo: os primeiros escritos políticos”, em MAQUIAVEL, Nicolau (2010). Maquiavel: política e gestão florentina. São Paulo: Fundação Getúlio Vargas.

VIROLI, Maurizio (1998). Machiavelli. Oxford: Oxford University Press. 
WOOD, Neal (1967). "Machiavelli's concept of virtue reconsidered". Political Studies, v. 15, n. 2, p. 159-72.

\section{Resumo:}

Este artigo analisa vinte e quatro textos menores de Maquiavel sobre a política, a maioria escrita durante seu serviço público na Chancelaria florentina. Esses textos são exemplos de ciência política aplicada e de propostas e estratégias em políticas públicas. Considerados em conjunto, eles oferecem novas oportunidades de pesquisa e perspectivas diferentes sobre a ciência política e o republicanismo de Maquiavel, inclusive no sentido de ajudar a resolver ambiguidades em suas obras principais, cujos propósitos e posições políticas ainda são objeto de debate e reavaliação. A discussão de cada um desses textos menores sobre a política com base em estudos recentes e sua colocação no contexto da política florentina doméstica e internacional sugere que o realismo de Maquiavel é temperado por um valor forte de republicanismo e de liberdade, interna e externa. Essas características do pensamento político de Maquiavel nem sempre são claras no Príncipe nem nos Discursos ou em outras grandes obras políticas e literárias que não eram resultado do serviço público de Maquiavel à república florentina.

Palavras-chave: Maquiavel, teoria política, história do pensamento político, republicanismo, Florença renascentista

\section{Abstract:}

This article reviews twenty-four minor texts by Machiavelli on politics, mostly from the period of his service in the Florentine Chancellery. The texts are examples of applied political science as well as policy proposals and strategies. Together, they provide new research opportunities and distinct insights into Machiavelli's political science and republicanism. They may help resolve ambiguities in his major works whose theoretical purpose and political positions are still subject to debate and evaluation. Discussion of each of those minor texts on politics based on recent studies and their placement within Florence's domestic and international politics suggest that Machiavelli's realism is tempered by a strong value of republicanism and freedom - internal and external. Such characteristics of machiavelli's political thought are not always clear in The Prince, the Discourses, and his other major political and literary works that were not part of Machiavelli's public service to the Florentine republic.

Keywords: Machiavelli, political theory, history of political thought, republicanism, Renaissance Florence.

Recebido em 29 de maio de 2013.

Aprovado em 20 de agosto de 2013. 